THE PARADOX OF THE PEASANTRY IN MANAGEMENT AND ORGANIZATION STUDIES

\begin{tabular}{|r|l|}
\hline Journal: & International Journal of Organizational Analysis \\
\hline Manuscript ID & IJOA-08-2021-2921.R1 \\
\hline Manuscript Type: & Original Article \\
\hline Keywords: & $\begin{array}{l}\text { peasantry, modern slavery, digitized agriculture, management and } \\
\text { farming, new space industry. }\end{array}$ \\
\hline \multicolumn{2}{|l}{} \\
\hline
\end{tabular}




\title{
THE PARADOX OF THE PEASANTRY IN MANAGEMENT AND ORGANIZATION
}

\section{STUDIES 1}

\begin{abstract}
Purpose - Burrell (2020) challenged management and organization studies (MOS) scholars to pay attention to a topic they have mostly ignored: the peasantry, those 2 billion people that work in the rural primary sector. We address the topic to expand Burrell's challenge by indicating that the peasantry offers a unique context to study a paradoxical condition: the coexistence of persistent poverty and vanguardist innovation.
\end{abstract}

Approach - We advance conceptual arguments that complement the reasons why researchers should pay more attention to the peasantry. We argue that continuation of past research into field laborers, transitioning from feudalism to industrial capitalism, still has currency, not just because of the good reasons listed by Burrell (enduring relevance of the phenomenon in developing countries; sustainability concerns; acknowledgment of common heritage) but also because some seemingly archaic practices are evident in the economically developed countries where most management and organizations scholars live.

Findings - We show that in advanced economies the peasantry has not disappeared, and it is manifest in contradictory forms, as positive force contributing to sustainable productivity (in the case of digitized agriculture) and as a negative legacy of social inequality and exploitation (as form of modern slavery)

\footnotetext{
${ }^{1}$ This work was funded by Fundação para a Ciência e a Tecnologia (UID/ECO/00124/2019, UIDB/00124/2020, UID/GES/00731/2019, UID/GES/00315/2019, and Social Sciences DataLab, PINFRA/22209/2016), POR Lisboa and POR Norte (Social Sciences DataLab, PINFRA/22209/2016)
} 
Originality - We discuss contrasting themes confronting management of the peasantry, namely modern slavery and digital farming, and propose that a paradox view may help overcome unnecessary dualisms which may promote social exclusion rather than integrated development.

Keywords: Peasantry, Modern slavery, Digitized agriculture, Management and farming, New space industry.

Paper type: Conceptual 


\section{INTRODUCTION}

Recently, Burrell (2020, p. 170) argued that business and management scholars, in contrast with scholarship from other disciplinary fields such as history, sociology and peasant studies (e.g., Mukhia, 1985) that has studied the role of worker cooperatives (Wiksell, 2020; Veta et al., 2016), for example, have "totally ignored" the peasantry, those 2 billion people that toil the land. He warned that the "death of the farmer", despite being announced several times, has yet to occur. He also highlighted that the peasantry are an important reservoir of knowledge that can contribute to our existential struggle to counteract global warming and that we must, in any case, acknowledge our own peasant heritage; go back a few generations and nearly all of us descended from peasants. Thus, he invites the MOS community to show respect and attention to the phenomenon, rather than assume that the peasantry is a historical remnant or has been largely eradicated.

Indeed, on the very rare occasions agriculture is mentioned in top management journals such as those of the Academy of Management, it is given a positive gloss, being associated with innovative forms of entrepreneurship (Hunt et al., 2019; Venkatesh et al., 2017) or with sophisticated forms of interorganizational cooperation (Boland and Katz, 2003; Boone and Özcan, 2014; Slade Shantz et al., 2019). In the broader organizational literature, as well, very little attention is given to the peasantry; typically, when it is, the context is one of struggle and resistance to globalization and neoliberalism (Özen and Özen, 2009; Pal, 2016; Qin et al., 2019). We engage paradox theory to explore tensions between the peasantry as a setting in which human exploitation and vanguardist innovation coexist, seeing these as a duality that integrates rather as a dualism that separates and excludes. Paradox refers to persistent oppositions between interdependent elements (Berti et al., 2021), such as those of technological advancement and human progress. Instead of seeing these two worlds as separate and following distinct paths (either-or version), it is important to find integrative "both-and" paradoxical solutions. In this way, technology will indeed follow a logic of integration 
rather than a bifurcation separating these two worlds. Major companies could integrate

environmental and human issues rather than choose between environmental or human issues (save nature or save labour).

We agree that study of the peasantry is worthwhile and present four orders of reasons, old and new, to augment and underline Burrell's call. First, in accord with Burrell's claim of the ongoing relevance of the peasantry, we note that the advent of industrial capitalism neither eliminated the peasantry nor did it made the specific challenges of farming irrelevant (Diaz-Villavicencio, 2020), but reorganized it so that the small-holding or plot might be supplemented by wage labor. Second, modern slavery is pervasive in the social formation of the peasantry in the "Western world". Third, digital transformation and new space technologies (Weinzierl, 2018) are transforming the face of agriculture, offering interesting opportunities for sustainable innovation with the advent of smart farming or agriculture 4.0, creating an innovative kind of digital peasantry (Klerkx et al., 2019). The linkages between digitization and the peasantry are widely discussed in the recent literature (Gluschenko et al., 2021; Prause et al., 2021; Tuchaeva et al., 2021). Fourth, the separate development of traditional farming and smart farming imposes a dualistic bifurcation representing different structures of ownership existing in different parts of the world. Doing so introduces distinct contextual conditions; however, it overlooks the extent to which the contradiction between the coexistence of poverty - even slavery - and technological vanguardism characterizing some contemporary rural sectors.

To ask the question, what is the emerging role of the peasantry in management and organization studies (MOS)?, we organize the article as follows: we start with a note on the transition from agriculture to industrial capitalism to situate our discussion. We next discuss two major topics in the contemporary debate on agriculture: modern slavery, and the emergence of digital agriculture. This dialectic of past and future is then used to compose a research agenda on the role of the peasantry in 
MOS. We contribute to the debate by responding to and expanding Burrell (2020), highlighting the coexistence of the medieval past and the digital future in this domain of activity.

\section{PREMODERN TIMES - THE TRANSITION TO INDUSTRIAL CAPITALISM}

Burrell is correct: not all peasants were made into the working classes in manufactories. Some were made into organized agrarian labor, a rural proletariat composed of four kinds of "master-servant relationship" (Thompson, 1968, p. 235): (1) casual labor, paid on a day-rate or piece-rate basis; (2) farm servants, hired by quarter or the year; (3) a regular labor-force, more or less fully employed the year round on the large farm, and; (4) more or less skilled specialists, who are able to contract for the job. Elements of this rudimentary division of labor remain evident today, with the proviso that, while in the past casual laborers (as well as farm servants) might have been recruited locally in hiring fairs (Hardy, 2004), today they are often recruited globally.

Depending on the country, the global casual workforce might be drawn from student backpackers overseas, in countries such as New Zealand and Australia. Within the EU, such labor will often be recruited from legal labor from Eastern European member states as well as from impoverished parts of Asia and Africa (Barrientos, 2013; Melossi, 2021). In The United States, a large proportion of the rural labor force is made of migrants, both legal and illegal (Sandovici, 2018). In the UK, they might consist of labor-hired gangs of undocumented migrants, recruited by an organization, either legal or criminal, depending on the policing of work visas in the nation and the availability of cheap labor from elsewhere. A classic case was the tragedy of the cockle pickers in Morecambe Bay in 2004 (Glover, 2014), in a revelation of a source of labor that is a new twist on old mode of production (Cooke, 2003): slavery. On the evening of $5^{\text {th }}$ February 2004, at Morecambe Bay in Northwest England, at least 21 Chinese illegal immigrant labourers were drowned by an incoming tide after picking cockles off the Lancashire coast. The tide moves swiftly and silently into the bay, almost imperceptibly, which locals know; illegal labourers and their gangmasters from far away would not. 
In the past, slavery was largely confined to black bodies that had been plundered from Africa to work on plantations in the Americas. Such slavery was formally abolished by the end of the $19^{\text {th }}$ century (1888 in Brazil) but that does not mean that there is not modern slavery in the contemporary world. Estimates suggest that modern slavery, including forced labor, affect more than 40 million people, 20 million of whom are trapped in corporate supply chains (Christ and Helliar, 2021). The phenomenon has received scant attention in MOS, even if is a widespread management practice (Crane, 2013).

\section{MODERN TIMES - MODERN SLAVERY}

Burrell remarked that while industrialization transformed peasants into the employees of the new factories, this transformation did not mean the end of the peasantry. In fact, billions of people still work in the sector, as we, in "this digitized world" still need "real food, produced by real people in real places far from our country" (Burrell, 2020, p. 171). Without those real, essential workers, the inhabitants of that digitized world wouldn't have flourished virtually during the pandemic. What is often ignored is that some of this food is produced not far away, in distant places, but in our countries by people in conditions close to modern slavery - where offenders use coercion, threats or deception to exploit victims and undermine their freedom. Those practices, happening in countries in which we live, can include human trafficking, servitude, forced labor, debt bondage, forced marriage, and child labor. Even in member states of the EU, where nationals prefer not to work on farms (Morén-Alegret and Wladyka, 2020), workers from impoverished parts of Asia and Africa work in conditions that the International Labor Organization would deem unacceptable (Caruana et al., 2021; Crane, 2013; Crane et al., 2021) to produce healthy foods, such as the berries that enrich our diets (Wallis, 2021). Modern slavery is an overlooked aspect of supply chain management (Gold et al., 2015; Monciardini et al., 2021; New 2015, 2020; Shilling et al, 2021).

Management and organization scholars need to consider how the peasantry of Asia may be a vital element in the supply chains underlying the organization and business model of modern slavery, not 
only in their countries but also as a globally mobile labor force (Wallis, 2020). Crane (2013) has offered a useful conceptual framework to guide this investigation, identifying conditions that are conducive to modern slavery, such as labor-intensive contexts, poverty and lack of education, entrenched traditions, and lack of governance and regulations. Clearly, the illegal employment of undocumented migrants for farm labor meets all these criteria.

Research is needed to investigate the nexus of deals that make this new slavery possible, including the clandestine supply chain, made of human traffickers, recruiting "gang masters", employers, exploitative "off-the-books" suppliers of lodging, etcetera, that enable the phenomenon. No successful mode of production can flourish without willing consumers who are indifferent to a product's provenance (Smith and Jones, 2020), as well as governments that turn a blind eye (sometimes resorting to economic growth and local/regional development arguments), even after they are alerted by the press. Indeed, investigating the network of vested interests that enables these forms of slavery entails precisely asking "who gains and who loses, and by which mechanisms of power?" (Flyvbjerg, 2004, p. 405). Analyzing why the idea of responsible production and consumption (Fisk, 1973) coexist with the exploitative practices offers an interesting opportunity to explore consumer attitudes. On the production side, given the importance of sustainable development goals (SDGs) for MOS (George et al., 2016), it can be important to explore how attention to goals such as decent work and life on land (more below) coexist peacefully with forms of necro-capitalist exploitation (Banerjee, 2008), including modern forms of slavery. The fascination with vanguardist innovation supporting precision farming should not divert scholarly attention from exploitative practices with which they coexist, sometimes in the same geographies, embedding archaic modes of production in the latest actant networks.

In his defense of the role of the ecology for 21 st century agriculture, Weiner (2003) emphasized the importance of trade-offs. For example, as he pointed out (p. 375), "principles of engineering suggest 
that the relationship between maximum short-term yield and sustainability will inevitably be negative." MOS scholars may contribute to the cross-disciplinary field connecting farming, supply chains, sustainability and organizing through applying paradox theory (Berti et al., 2021; Smith and Lewis, 2011). Paradox theory has developed rapidly, accentuating that contradictions are inherent to organizational activity whose management is an integral component of management. The paradox of industrialized agriculture aptly illustrates that, as a sector that is increasingly pressured to show its green credentials, it may do so at the cost of downplaying its concern about the social pollution (Pfeffer, 2010) it creates, in a clear case of "solving" paradox by reducing expectations (Li, 2021). The challenge thus lies in building regenerative businesses (Hahn and Tampe, 2021), able to treat tensions through a logic of paradox rather than organizing them through exploitation.

C. Wright Mills (1959) alerted social science to the fact that what are often experienced as personal troubles and private problems have public dimension. Mills (1959) identified the fact that we function in our personal lives as best we can, given the circumstances in which we find ourselves. These circumstances, however, are rarely matters of individual choice. They are framed by larger social or public issues that lie beyond personal control, framing one's opportunities. They pertain to social organization and processes rooted in social relations and networks rather than in individual volitions. Peasants from Thailand do not necessarily desire to be fruit pickers earning their living in the far north of Europe, nor do Chinese peasants desire to put themselves somewhere they can be drowned. Being engulfed in a fast-moving tide in Morecambe Bay while picking cockles is not a matter of individual choice but of the way that agriculture is organized in the modern world and the opportunities it affords some people with little choice. "Neither the life of individual nor the history of a society can be understood without understanding both", as Mills (2010, p. 5) wrote; the same might be said of the death of the individual. 
We require more integrative analyses of how past and future, production and consumption, human and natural environmental factors interact to create private troubles that are neglected as public issues by MOS. Shareholders have been more alert to some aspects of these issues. Food companies trying to balance planet and profits and to integrate responsible production and responsible consumption (McCluskey et al., 2009) are faced with important challenges, as illustrated by the recent demise of Danone's CEO, Emmanuel Faber (van Gansbeke, 2021). The board of Danone sacked Faber because of pressure from activist shareholders Bluebell Capital Partners and Artisan Partners, which pressed toward shareholder value rather than the social value of stakeholder capitalism and Environmental, Social, Governance (ESG) objectives that Faber endorsed. Rival major food groups such as Nestlé and Unilever were far more profitable, in part because COVID-19 hit Danone's bottled water sales to restaurant hard; irrespective of the reason, the resistance was organized around the banner of shareholder versus social value. Social value as a consideration in agricultural food as well as cash crop production must take into account those people that labour at the bottom of the pyramid, often unrepresented by the state, unions and political parties if only because most peasants are not affiliated with existing institutions, therefore being excluded from political debates, outside the scope of the existing political circuits (Clegg, 1989) and thus represented by no one. Corporations that take ESG objectives seriously have an important role to play in this space, which is why the resistance to Danone's pursuit of these objectives is retrograde in terms of a consideration of commercial interests in the condition of the peasantry.

\section{POSTMODERN TIMES - PRECISION PEASANTS}

Burrell invited us to study the peasantry as something "grounded" in an increasingly digitized world. However, while one strand of writing on the new peasantry stresses ecological embeddedness (Ploeg, 2008), another stresses a small new peasantry working on "a limited number of elite farms operate agriculture employing new technologies such as Internet of Things (IoT) and Artificial Intelligence 
(AI) and exporting their products to international markets" (Sekine, 2021, p. 49). In this scenario, agriculture is becoming increasingly digital, with the new peasantry increasingly comprising knowledge workers. Some critics, such as Pelek (2019), see such scenarios as a part of "neoliberal restructuring" while others see new peasants as people that show respect to "traditional knowledge and cultures, pay attention to their communities, secure generational succession of family and farms, and operate pluriactively ...They are keen to maintain agricultural biodiversity and microorganisms in soils through self-seeding and create agricultural tools according to necessities" (Sekine, 2021, p. 51).

The new peasantry is composed not only of small-scale family farms but also "subsistence farmers, hobby farmers, edible school yards and community gardens [that] must be measured, paid more political attention, and allocated public support" (Leff, 2021, p. 52). Schemes that "promote Community Supported Agriculture (CSA), public procurement of organic and localized agri-food products, farmers' markets for agroecological products in every primary school district, local foods manufactured by local small-and-medium-sized processors, grounded agritourism and agri-food and nutrition education would be the components of these policies" (Leff, 2021, p. 52). A new peasantry results from a return to agriculture as a viable occupation in some advanced economies, according to some authorities (Milone and Ventura, 2019; Öztürk et al., 2018; Xie, 2021). Combined with the previous discussion it seems that agriculture is at a bifurcation point, a crossroads where one path leads to practices with medieval undertones and the other resembles science fiction innovation.

The emergence of new agricultural practices, such as precision agriculture, results from developments in several fields, including agronomic sciences but also sustainability, automation, and the new space industries (Gardezi and Stock, 2021; Medici et al., 2021). The convergence of these technologies is changing the face of agriculture - and some of those innovative practices may contribute to reduce vulnerability and risk of (immigrant, but not only) worker populations (Christ 
and Helliar, 2021). New farming practices are central to moves in the direction of at least five sustainable development goals: 1 (no poverty), 2 (zero hunger), 8 (decent work), 12 (responsible production and consumption) and 15 (life on land).

Contemporary applications of technologies such as vertical agriculture and hydroponic agriculture are changing the face of agriculture, as are other digital developments (Martin and Molin, 2019). Central new developments in agriculture include automatic control devices as well as digital data to input into decision-making, which are termed precision agriculture (or precision farming). Central to these new forms of farming are global positioning system (GPS) (Brisco et al, 1998; Cox, 2002). Shafi et al. (2019) note that the IoT now encompasses automation of agricultural events in ways that are digitally dynamic and smart in responding to changing contingencies, using wireless sensor networks as well as precision agriculture to control optimal fertilizing and watering for productivity and sustainability, based on data about the conditions of soil, crops and weather from remote fieldbased sensors. Using GPS and drones, high resolution surveillance provides data to feed into strategic decision-making.

Agrarian labor must be increasingly smart, with peasants being no exception. There is some inquiry in these areas (Hossain et al., 2020; Stotten, 2020) but the surface is barely scratched. Nonetheless, the potential negative impacts of the re-composition of the agricultural workforce should also be considered. New technologies such as agricultural robotics (Shamshiri et al., 2018) may render the existing workforce irrelevant in the search for better solutions, but what will this mean in terms of local, tacit knowledge accumulated over the years? Some authors see the risks of these new technologies being that of exclusion of small, peasant and agroecological farmers from participating in agro-food production (Rotz et al., 2019). Others point to the problems of techno-optimism, such as Passero (2021, p. 8) for whom introducing digital technology will always "activate the network of relationships of the technological ecosystem that make and give meaning to that device”. These 
networks entail that consideration be given to "data sovereignty" in relation to the people and projects that digitization is organizing amongst the world's peasantry (Fraser, 2020).

The new peasantry as a phenomenon can have a positive impact by drawing the attention of urban dwellers to a common existential connection to nature, alerting urbanites to the necessity of sustainable choices and the role that sophisticated digital technologies can play in augmenting this connection. The development of "urban farming" initiatives also goes some way to achieving this goal (Sarker et al., 2019). However, we must also be alert to the possible negative implications, such as the gentrification of farming resulting from the acquisition of farmland by the wealthy elite to pursue "life-style" choices (Sutherland, 2012) whose arcadia is serviced by the labor of a rural but proletarianized peasantry, producing poverty and exclusion rather than harmony and sustainable futures. Agriculture is an important and unexplored field in which to study the process of digital transformation, usually thought of as being mostly associated with computers, services and the trend toward servitization. It is also a field to which scholars involved in human sustainability and ethics must pay more attention given the reasons delineated above. Table 1 illustrates some of the opportunities for future work.

Table 1 about here

As a complement to the present argument, researchers may study peasantry as a specific mode of organizing in contemporary economies rather than a residual legacy of pre-capitalist modes of production (Hindess and Hirst, 2017). Peasantry organizes a way of production but also ways of living and relating to nature, to family, to social relations and to consumption. Several lines of work have been opened in this stream already, including the logic of decreasing growth or degrowth (Kallis et al., 2018; Latouche, 2009). The peasantry is not some immutable residue or legacy of antiquity; the application of new space technologies in farming, for instance, is a lever to reduce pressures on the environment and create opportunities for alternative logics of production. The use of 
water and land can be rendered less intensive if new technologies are made available to farmers in less developed regions. The adoption of these technologies will not necessarily be easy as farmers may resist them because of a lack of trust or knowledge (Rogers, 2010). Of course, instead of promoting social development, new technologies may instead aggravate the exclusion of the poor.

\section{FINAL REMARKS}

In many countries in the EU, from the picking of cloud berries in the far north of Scandinavia to the cultivation of olives and strawberries in Portugal, the three practices discussed here coexist, the archaic tangled up with the modern and the post-modern. Agriculture thus seems to constitute a fertile terrain to explore several topics with incredible potential: the historical coexistence of past and future, sustainability, innovation, technology, and supply chains composed of globally mobilized humans. In summary, we consider that Burrell's (2020) proposal is correct - for all the reasons he advanced as well as for the additional reasons deployed here.

There is clearly something going on in the greenhouses, fields, plantations, and forests that many management and organizations scholars rarely think about in their research work. Work, its management and organization, occurs not only in factories and offices. Many of us, as management and business scholars, have little idea about what happens in agrarian and rural practice; executives from agri-businesses rarely appear in executive training activities in urban-based business schools in part, we suspect, because they intuit that our "theories" are far from their realities and calculations. As our discussion indicates, the peasantry, as well as those that organize them, deserve to be studied not only for those reasons enunciated by Burrell (2020). Our note should not be read as countering Burrell: on the contrary, we suggest that there is even more necessity to study the peasantry than the excellent reasons that he presented. 


\section{REFERENCES}

Banerjee, S.B. (2008). “Necrocapitalism”. Organization Studies, 29(12), 1541-1563.

Barrientos, S. W. (2013). “'Labour chains': Analysing the role of labour contractors in global production networks". The Journal of Development Studies, 49(8), 1058-1071.

Berti, M., Simpson, A.V., Cunha, M.P. and Clegg, S. (2021). Elgar introduction to organizational paradox theory. Cheltenham: Edward Elgar.

Bhakoo, V., and Meshram, K. (2021). "Modern slavery in supply chains”. Maak, T., Pless, N.M., Orlitzky, N. and S. Sandhu, N. (Eds.), The Routledge companion to corporate social responsibility (pp. 246-259). London: Routledge.

Boland, M. A., and Katz, J. P. (2003). “Jack Gherty, president and CEO of Land O'Lakes, on leading a branded food and farm supply cooperative". Academy of Management Perspectives, 17(3), 24-30.

Boone, C., and Özcan, S. (2014). "Why do cooperatives emerge in a world dominated by corporations? The diffusion of cooperatives in the U.S. Bio-ethanol industry, 1978-2013". Academy of Management Journal, 57(4), 990-1012.

Brisco, B., Brown, R. J., Hirose, T., McNairn, H., and Staenz, K. (1998). "Precision agriculture and the role of remote sensing: A review”. Canadian Journal of Remote Sensing, 24(3), 315-327.

Burrell, G. (2020). "W(h)ither the peasantry in the work of the Academy?" Academy of Management Discoveries, 6(2), 170-171.

Caruana, R., Crane, A., Gold, S., and LeBaron, G. (2021). "Modern slavery in business: the sad and sorry state of a non-field”. Business \& Society, 60(2), 251-287. 
Christ, K. L., and Helliar, C. V. (2021). "Blockchain technology and modern slavery: Reducing deceptive recruitment in migrant worker populations." Journal of Business Research, 131, 112120.

Clegg, S. (1989). Frameworks of power. Sage: London.

Cox, S. (2002). "Information technology: the global key to precision agriculture and sustainability". Computers and Electronics in Agriculture, 36(2-3), 93-111.

Crane, A. (2013). "Modern slavery as a management practice: Exploring the conditions and capabilities for human exploitation". Academy of Management Review, 38(1), 49-69.

Crane, A., LeBaron, G., Phung, K., Behbahani, L., and Allain, J. (2021). “Confronting the business models of modern slavery”. Journal of Management Inquiry, 1056492621994904.

Diaz-Villavicencio, G. (2020). "Innovation management practices: analysis of small family farmers on the border of Brazil and Paraguay". International Journal of Organizational Analysis, 28(6), 1243-1254.

Fisk, G. (1973). “Criteria for a theory of responsible consumption”. Journal of Marketing, 37(2), 2431.

Flyvbjerg, B. (2004). “A Perestroikan straw man answers back: David Laitin and phronetic political science". Politics \& Society, 32, 389-416.

Fraser, A. (2020). The digital revolution, data curation, and the new dynamics of food sovereignty construction. The Journal of Peasant Studies, 47(1), 208-226.

Gardezi, M., and Stock, R. (2021). “Growing algorithmic governmentality: Interrogating the social construction of trust in precision agriculture". Journal of Rural Studies, 84, 1-11. 
George, G., Howard-Grenville, J., Joshi, A. and Tihanyi, L. (2016). "Understanding and tackling societal grand challenges through management research". Academy of Management Journal, 59(6), 1880-1895.

Glover, A. (2004) “Slavery 'worse' 10 years after Morecambe Bay tragedy”, BBC News, https://www.bbc.com/news/uk-england-25914594, accessed 12.08.21.

Glushchenko, T. E., Khodarinova, N. V., Ishchenko, O. V., Shaposhnikov, V. L., and Aksenova, Z. A. (2021). "The Development of Cooperation in the Digital Economy Based on Scientific Research". in Chayanov, A.V, Bogoviz, A. V., Suglobov, A. E., Maloletko, A. N., Kaurova, O. V., and Lobova, S. V. (Eds.) Frontier Information Technology and Systems Research in Cooperative Economics (pp. 43-52). Berlin: Springer.

Gold, S., Trautrims, A. and Trodd, Z. (2015). "Modern slavery challenges to supply chain management”. Supply Chain Management: An International Journal, 20(5), 485-494.

Hahn, T., and Tampe, M. (2021). "Strategies for regenerative business". Strategic Organization, 19(3), 456-477.

Hardy, T. (2004). The mayor of Casterbridge. Oxford: Oxford University Press.

Hindess, B., and Hirst, P. Q. (2017). Pre-capitalist modes of production. London: Routledge.

Hossain, A., Hamja, M. A. A., Ahmed, F. and Arafat, K. M. (2020). "Exploring the behavior of app developers and the future of digital Bangladesh”. European Journal of Social Sciences (EJSS), 59(3), 255-264. 
Hunt, R. A., Townsend, D., Korsgaard, S., and Naar, A. (2019). "Urban farmers and cowboy coders: Re-imagining rural venturing in the 21 st century". Academy of Management Perspectives, https://doi.org/10.5465/amp.2017.0157.

Kallis, G., Kostakis, V., Lange, S., Muraca, B., Paulson, S., and Schmelzer, M. (2018). "Research on degrowth". Annual Review of Environment and Resources, 43, 291-316.

Klerkx, L., Jakku, E. and Labarthe, P. (2019). “A review of social science on digital agriculture, smart farming and agriculture 4.0: New contributions and a future research agenda". NJASWageningen Journal of Life Sciences, 90, 100315.

Latouche, S. (2009). Farewell to growth. Polity.

Leduc, G., Kubler, S., and Georges, J. P. (2021). "Innovative blockchain-based farming marketplace and smart contract performance evaluation”. Journal of Cleaner Production, 306, 127055.

Leff, E. (2021). "Revaluing Nature: From Exploitation of Peasantry in Capitalism to Emancipation of Indigenous Peoples and Sustainability of Life on Earth". In Political Ecology: Deconstructing Capital and Territorializing Life (pp. 141-164). Palgrave Macmillan.

Li, X. (2021). "Solving paradox by reducing expectation". Academy of Management Review, 46(2), 406-408.

Martin, M., and Molin, E. (2019). "Environmental assessment of an urban vertical hydroponic farming system in Sweden”. Sustainability, 11(15), 4124.

McCluskey, J. J., Durham, C. A., and Horn, B. P. (2009). “Consumer preferences for socially responsible production attributes across food products". Agricultural and Resource Economics Review, 38(3), 345-356. 
Medici, M., Pedersen, S. M., Canavari, M., Anken, T., Stamatelopoulos, P., Tsiropoulos, Z., Zotos, A. and Tohidloo, G. (2021). "A web-tool for calculating the economic performance of precision agriculture technology". Computers and Electronics in Agriculture, 181, 105930.

Melossi, E. (2021). "Ghetto tomatoes" and "taxi drivers": The exploitation and control of SubSaharan African migrant tomato pickers in Puglia, Southern Italy. Journal of Rural Studies, https://doi.org/10.1016/j.jrurstud.2021.04.009.

Menton, M., Larrea, C., Latorre, S., Martinez-Alier, J., Peck, M., Temper, L., and Walter, M. (2020). “Environmental justice and the SDGs: from synergies to gaps and contradictions". Sustainability Science, 15(6), 1621-1636.

Mills, C. W. (1959). The sociological imagination. Harmondsworth: Penguin.

Mills, C. W. (2010). "Private troubles, public issues". Giddens, A. and Sutton, P. W. (eds), Sociology: Introductory Readings (pp. 5-8). Cambridge: Polity.

Milone, P., and Ventura, F. (2019). "New generation farmers: Rediscovering the peasantry". Journal of Rural Studies, 65, 43-52.

Monciardini, D., Bernaz, N. and Andhov, A. (2021). "The organizational dynamics of compliance with the UK Modern Slavery Act in the food and tobacco sector”. Business \& Society, 60(2), 288-340.

Morén-Alegret, R. and Wladyka, D. (2020). Immigration, integration and sustainability in small towns and villages: Socio-territorial challenges in rural and semi-rural Europe. PalgraveMacmillan. 
Mukhia, H. (1985). "Peasant production and medieval Indian society”. The Journal of Peasant Studies, 12(2/3), 228-251.

New, J. S. (2015). "Modern slavery and the supply chain: the limits of corporate social responsibility?” Supply Chain Management: An International Journal, 20(6), 697-707.

New, S. (2020). “Modern slavery and supply chain transparency”. In Choi, T. Y., Li, J.L., Rogers, D.S., Schoenherr, T. and Wagner, S.M. (Eds), The Oxford Handbook of Supply Chain Management. DOI: 10.1093/oxfordhb/9780190066727.013.1

Özen, S and Özen, H. (2009). "Peasants against MNCs and the state: The role of the Bergama Struggle in the institutional construction of the gold-mining field in Turkey". Organization, $16(4), 547-573$.

Öztürk, M., Jongerden, J., and Hilton, A. (2018). "The (re) production of the new peasantry in Turkey". Journal of Rural Studies, 61, 244-254.

Pal, M. (2016). “Organization at the margins: Subaltern resistance of Singur”. Human Relations, 69(2), 419-438.

Pelek, D. (2019). “Syrian refugees as seasonal migrant workers: Re-construction of unequal power relations in Turkish agriculture". Journal of Refugee Studies, 32(4), 605-629.

Ploeg, J. D. van der (2008) The New Peasantries: Struggles for Autonomy and Sustainability in an Era of Empire and Globalization, London: Earthscan.

Prause, L., Hackfort, S., and Lindgren, M. (2021). "Digitalization and the third food regime". Agriculture and Human Values, 38(3), 641-655. 
Qin, X., Hom, P. W., and Xu, M. (2019). “Am I a peasant or a worker? An identity strain perspective on turnover among developing-world migrants". Human Relations, 72(4), 801-833.

Rogers, E. M. (2010). Diffusion of innovations. Simon and Schuster.

Rotz, S., Duncan, E., Small, M., Botschner, J., Dara, R., Mosby, I., ... and Fraser, E. D. (2019). “The politics of digital agricultural technologies: a preliminary review”. Sociologia Ruralis, 59(2), 203-229.

Sandovici, M. E. (2018). "Legal yet enslaved: The case of migrant farm workers in the United States". In Bryson Clark J., and Poucki, S. (Eds.), The SAGE handbook of human trafficking and modern day slavery (pp.424-433.). London: Sage.

Sarker, A. H., Bornman, J. F., and Marinova, D. (2019). “A framework for integrating agriculture in urban sustainability in Australia". Urban Science, 3(2), 50.

Shafi, U., Mumtaz, R., García-Nieto, J., Hassan, S. A., Zaidi, S. A. R., and Iqbal, N. (2019).

"Precision agriculture techniques and practices: From considerations to applications". Sensors, 19(17), 37-96.

Shamshiri, R.R., Weltzien, C., Hameed, I.A., Yule, I.J., Grift, T.E., Balasundram, SK., Pitonakova, L., Ahmad, D and Chowdhary, G. (2018). "Research and development in agricultural robotics: A perspective of digital farming”. International Journal of Agricultural and Biological Engineering 11(4), 1-14.

Shilling, H. J., Wiedmann, T., and Malik, A. (2021). "Modern slavery footprints in global supply chains". Journal of Industrial Ecology, https://doi.org/10.1111/jiec.13169 
Slade Shantz, A. F., Kistruck, G. M., Pacheco, D. F. and Webb, J. W. (2019). "How formal and informal hierarchies shape conflict within cooperatives: A field experiment in Ghana". Academy of Management Journal, 63(2), 503-529.

Smith, A., and Johns, J. (2020). "Historicizing modern slavery: free-grown sugar as an ethics-driven market category in nineteenth-century Britain”. Journal of Business Ethics, 166(2), 271-292.

Smith, W. K., and Lewis, M. W. (2011). "Toward a theory of paradox: A dynamic equilibrium model of organizing”. Academy of Management Review, 36(2), 381-403.

Smith, W. K., Gonin, M. and Besharov, M. L. (2013). "Managing social-business tensions: A review and research agenda for social enterprise". Business Ethics Quarterly, 23(3), 407-442.

Smith, W. K., Lewis, M. W. and Tushman, M. L. (2016). "Both/and leadership”. Harvard Business Review, 94(5), 62-70.

Stotten, R. (2020). "The role of farm diversification and peasant habitus for farm resilience in mountain areas: the case of the Ötztal valley, Austria". International Journal of Social Economics, 48(7), 947-964.

Sutherland, L.-A. (2012). "Return of the gentleman farmer? Conceptualising gentrification in UK agriculture". Journal of Rural Studies, 28(4), 568-576.

Thompson, E. P. (1968). The making of the English working class. Harmondsworth: Penguin.

Turchaeva, I. N., and Golovach, V. M. (2021). Digital Transformations in Agriculture as a Factor of Sustainable Rural Development. In Bogovitz, A. V. (ed.) Complex Systems: Innovation and Sustainability in the Digital Age (pp. 517-524). Berlin: Springer. 
Van Gansbeke, F. (2021). "Sustainability and the downfall of Danone CEO Faber (1\&2)". Forbes, March 20. Available at

https://www.forbes.com/sites/frankvangansbeke/2021/03/20/sustainability-and-the-downfallof-danone-ceo-faber-12/?sh=1b1208775b16, accessed 28.07.21.

Venkatesh, V., Shaw, J. D., Sykes, T. A., Wamba, S. F., and Macharia, M. (2017). "Networks, technology, and entrepreneurship: A field quasi-experiment among women in rural India”. Academy of Management Journal, 60(5), 1709-1740.

Vieta, M., Quarter, J., Spear, R., and Moskovskaya, A. (2016). “Participation in worker cooperatives". In The Palgrave handbook of volunteering, civic participation, and nonprofit associations (pp. 436-453). Palgrave Macmillan, London.

Wallis, E. (2021). "Thai migrant workers pay for the "privilege" of picking berries in Sweden", InfoMigrants, Available at https://www.infomigrants.net/en/post/28600/thai-migrant-workerspay-for-the-privilege-of-picking-berries-in-sweden, accessed 27.06.21.

Weiner, J. (2003). "Ecology-the science of agriculture in the 21st century". The Journal of Agricultural Science, 141(3-4), 371-377.

Weinzierl, M. (2018). "Space, the final economic frontier". Journal of Economic Perspectives, 32(2), 173-192.

Wiksell, K. (2020). "Worker cooperatives for social change: Knowledge-making through constructive resistance within the capitalist market economy". Journal of Political Power, 13(2), 201-216.

Xie, X. (2021). "New Farmer Identity: The Emergence of a Post-Productivist Agricultural Regime in China”. Sociologia Ruralis, 61(1), 52-73. 
Yang, C., Everitt, J. H., Du, Q., Luo, B., and Chanussot, J. (2012). "Using high-resolution airborne and satellite imagery to assess crop growth and yield variability for precision agriculture". Proceedings of the IEEE, 101(3), 582-592. 
Table 1

Peasantry in MOS: Research opportunities beyond dualism

\begin{tabular}{|c|c|c|c|}
\hline & Modern slavery & Digital Farming & Paradoxical both-anding \\
\hline Key questions & $\begin{array}{l}\text { Understanding how slavery } \\
\text { in its modern expressions } \\
\text { infiltrated the agricultural } \\
\text { sector in advanced } \\
\text { economies. }\end{array}$ & $\begin{array}{l}\text { How are digital technologies } \\
\text { affecting agricultural firms and } \\
\text { their workers, creating a new } \\
\text { digital peasantry? }\end{array}$ & $\begin{array}{l}\text { How new technologies } \\
\text { can be used to support } \\
\text { more sustainable forms of } \\
\text { poverty reduction. }\end{array}$ \\
\hline \multirow[t]{5}{*}{$\begin{array}{l}\text { Research } \\
\text { opportunities }\end{array}$} & \multirow{5}{*}{$\begin{array}{l}\text { Why are developed societies } \\
\text { complacent with modern } \\
\text { forms of slavery in their own } \\
\text { countries? } \\
\text { How does (ir)responsible } \\
\text { production coexist with } \\
\text { (ir)responsible consumption? } \\
\text { What is the attitude of unions } \\
\text { and progressive political } \\
\text { parties regarding these new } \\
\text { forms of exploitation? }\end{array}$} & \multirow{4}{*}{$\begin{array}{l}\text { How are digital technologies } \\
\text { recomposing the peasant } \\
\text { workforce with what } \\
\text { consequences for the rural } \\
\text { world? } \\
\text { What is the role of precision } \\
\text { farming in the search for } \\
\text { sustainable solutions? }\end{array}$} & $\begin{array}{l}\text { How can new space } \\
\text { technologies be used to } \\
\text { promote more sustainable } \\
\text { use of land and water? }\end{array}$ \\
\hline & & & \multirow{3}{*}{$\begin{array}{l}\text { How can new } \\
\text { technologies participate in } \\
\text { more sustainable modes } \\
\text { of living? }\end{array}$} \\
\hline & & & \\
\hline & & & \\
\hline & & $\begin{array}{l}\text { How does digital farming affect } \\
\text { agricultural business models? }\end{array}$ & $\begin{array}{l}\text { What are the political } \\
\text { challenges involved in a } \\
\text { fair use of precision } \\
\text { farming technologies? }\end{array}$ \\
\hline Illustrative work & $\begin{array}{l}\text { Gold et al. (2015); } \\
\text { Monciardini et al. (2021); } \\
\text { New et al. (2015, 2020); } \\
\text { Shilling et al. (2021) }\end{array}$ & $\begin{array}{l}\text { Rijswijk et al. (2021); Shang et } \\
\text { al. (2021); Hossain et al. } \\
(2020) \text {; Stotten (2020) }\end{array}$ & $\begin{array}{l}\text { Menton et al. (2020); } \\
\text { Yang et al. (2012) }\end{array}$ \\
\hline
\end{tabular}

